\title{
Research of How to Cultivate the Applied Talents under School-enterprise Collaboration
}

\author{
Ping-ping Xiao* \\ office of academic affairs \\ Changchun Guanghua University \\ Changchun, China
}

\author{
Yong Zhang \\ Institute of electrical and information \\ Changchun Guanghua University \\ Changchun, China
}

\begin{abstract}
On the basis of the purpose of cultivating applied talents, through the relevant ideas of the depth of cooperation between school and enterprise, we investigate and analyze of the demand market for undergraduate talents, and recheck, readjust and construct the professional direction, and clearly define the needs of various professions for the social and industry positions. By closely combining the own special education of school and cognitive ability of students, we orient the target of talent training, reform and innovate teaching mode, form the target of talent training with the characteristics of our school, and improve the quality of education and te aching.
\end{abstract}

Keywords-applied talents; training mode; the collaboration of school and enterprise

\section{INTRODUCTION}

The training mode of applied talents refers to design of the training specifications of applied talents under the guidance of the educational thought of cultivating applied talents ${ }^{[1]}$. It implements the docking of professional setting and industrial demand, the docking of curriculum content and professional standards, the docking of the teaching process and the production process, and applies multi-subject to evaluate the quality of cultivating talents. The purpose of the way is to "learn to apply".

\section{APPLIED TALENTS TRAINING MODE IN SCHOOL- ENTERPRISE COLLABORATION}

In order to adapt to the trend of the development of national and local strategic new industries, with a view to the talent demand of the economic and social development to the field of Internet of things engineering ${ }^{[2]}$, our IoT engineering profession has carried out a deep cooperation with Chinasoft International in 2012. The students will sign an employment agreement when they enter into the university. We implement a "2.5+0.5+1" talent training model (that is the students study professional basic knowledge in the school for 2.5 years, study the course of professional direction to the training base of enterprise for 0.5 year, and carry out practice, training, graduation design to the soft cooperative enterprises for 1 years).The enterprise participates in the whole teaching process, including the formulation of talent training programs, new enrolment education, the embedded curriculum training of enterprise, graduation design, teacher training, enterprise

practice, employment service and so on. The mode ensures the

This work was financially supported by the Jilin new engineering research and practice project. employment of students. Relying on the platform of school enterprise cooperation, we try to the training mode of embedded talents in whole enterprise, explore the operating mechanism of schools, cooperative enterprises and social (employment), and implement the cooperative model of 'jointly formulate training programs, jointly implement training process, jointly develop teaching resources and jointly monitor teaching quality", and construct a 'platform+module' curriculum system, create the characteristics of the IoT engineering professional, and enhance the competitiveness of students employment ${ }^{[3]}$.

\section{A. Oriented-orientation Talent Training Goal}

In order to achieve the goal of training applied talents and accurately grasp the position of the talents training of the IoT engineering profession, we set up the professional construction guidance committee which was attended by industry and enterprise personnel at the beginning of the revision of the talent training program. We did a survey and analysis to the demand for talents in the IoT (see Table 1), the main field of employment and the work needed. We focus on understanding the requirements of the employers' ability, knowledge and quality on the needs of the personnel to the relevant posts in the process of investigation, and aim at the knowledge, ability and quality of the needs of the actual posts to determine the professionals that meet the needs of the market ${ }^{[4]}$. We realize the transformation from the enrollment market orientation to the employment market orientation.

TABLE I. ANALYSIS OF T ALENT DEMAND FROM THE IOT INDUSTRY CHAIN

\begin{tabular}{|c|c|c|}
\hline Link & Function & The working position \\
\hline $\begin{array}{l}\text { Perceptual } \\
\text { control }\end{array}$ & $\begin{array}{c}\text { mainly use to perceive } \\
\text { information from the device, } \\
\text { involving hardware system of } \\
\text { IoT }\end{array}$ & \multirow{3}{*}{$\begin{array}{c}\text { Internet products } \\
\text { development / system } \\
\text { integration engineer, IoT } \\
\text { technology support, IoT } \\
\text { pre-sales / after-sales } \\
\text { engineer, IoT product sales } \\
\text { personnel, embedded } \\
\text { system engineer, IoT } \\
\text { software and hardware } \\
\text { tester, etc }\end{array}$} \\
\hline $\begin{array}{c}\text { Data } \\
\text { transmission }\end{array}$ & $\begin{array}{l}\text { mainly transmit the perceived } \\
\text { information by the network, } \\
\text { involving computer network and } \\
\text { communication technology }\end{array}$ & \\
\hline $\begin{array}{c}\text { Data } \\
\text { processing }\end{array}$ & $\begin{array}{c}\text { mainly deals with data } \\
\text { transmitted, involving system } \\
\text { analysis }\end{array}$ & \\
\hline
\end{tabular}

B. Oriented-ability Modular Curriculum System

Through the investigation and analysis of the related posts in the IoT industry, we clarify the training targets and training specifications of the IoT engineering profession, and 
determine the professional ability corresponding to the various stages of perception, transmission and application of IoT $^{[5]}$. We decompose the professional foundation, core, engineering practice and scientific and technological innovation ability which need for the job, and make it to a number of ability elements under taking full consideration of the relationship the specific capability elements of different modules, and then decompose the large capacity modules into a shallow and interconnected curriculum module.

In order to achieve the training goal of oriented-ability, schools should rely on the curriculum and teaching system as a platform. The curriculum system is the important means and guarantees to transform the training target into the specific educational practice. It is the main basis for training the talents and the organization of the teaching, which is directly related to the quality of the talent training. Therefore, the construction of the applied undergraduate education model must focus on the objective requirements of the harmonious development of the knowledge, ability and quality of applied undergraduate talents. We construct a curriculum system with the mainline of application ability training.

The key words of the reconstruction of the curriculum system are the integration ${ }^{[6]}$, we implement the construction of the curriculum group which aims at the curriculum integration. According to the requirements of the post, the curriculum module is the unit according to the requirements. The integration of the theoretical curriculum is centered on the professional core ability, integrated of related courses, compressed of redundant learning. The integration of practice link is changed from dependent on curriculum to meta synthesis. The ability matrix of "post-ability-course"is constructed, which take the training of professional core competence as the main line, and form the orientedapplication theoretical course system and the oriented-ability practical training system, highlight the training characteristics of applied talents with the combination of learning and application.

TABLE II. THE MODULAR CURRICULUM SYSTEM BASED ON ORIENTED-ABILITY

\begin{tabular}{|c|c|c|c|}
\hline Capacity level & Capacity decomposition & Corresponding curriculum module & Bear party \\
\hline \multirow{4}{*}{ Professional basic ability } & Computing ability & $\begin{array}{l}\text { Higher mathematics, linear algebra, probability theory and mathematical } \\
\text { statistics }\end{array}$ & \multirow{6}{*}{ school } \\
\hline & Experimental ability & $\begin{array}{l}\text { Experimental links of professionalbasic courses and professional } \\
\text { courses }\end{array}$ & \\
\hline & Hardware technical ability & $\begin{array}{l}\text { Circuit and electronic technology, digital logic and systemdesign, } \\
\text { principle and application of single chip microcomputer, design of } \\
\text { embedded system }\end{array}$ & \\
\hline & Software technical ability & $\begin{array}{l}\text { C language programming, object oriented programming, data structure, } \\
\text { operating system, database system }\end{array}$ & \\
\hline \multirow{6}{*}{ Professional core ability } & $\begin{array}{c}\text { Information perception ability of } \\
\text { IoT }\end{array}$ & $\begin{array}{l}\text { RFID principle and application, sensor principle and application, sensor } \\
\text { network principle and Application }\end{array}$ & \\
\hline & $\begin{array}{l}\text { information transmission capacity } \\
\text { of IoT }\end{array}$ & Internet of things communication technology, computer network & \\
\hline & \begin{tabular}{|c|} 
Development of embedded Linux C \\
language
\end{tabular} & $\begin{array}{l}\text { enterprise level C language reinforcement, C program design under } \\
\text { Linux }\end{array}$ & \multirow{4}{*}{ enterprise } \\
\hline & \begin{tabular}{|c|}
$\begin{array}{c}\text { Advanced programming of } \\
\text { embedded Linux system }\end{array}$ \\
\end{tabular} & Linux application development, advanced programming of Linux system & \\
\hline & $\begin{array}{l}\text { Graphics development of embedded } \\
\text { Linux system }\end{array}$ & $\mathrm{C}++$ programming strengthening, visual programming of Linux system & \\
\hline & $\begin{array}{c}\begin{array}{c}\text { Construction of IoT system and } \\
\text { wireless sensor technology }\end{array} \\
\end{array}$ & $\begin{array}{l}\text { Design and implementation of IoT systemlayer, IoT engineering design } \\
\text { and implementation, IoT control, IOT information security technology }\end{array}$ & \\
\hline \multirow{2}{*}{ Engineering practice ability } & \multicolumn{2}{|c|}{ Data structure course design, embedded systemcourse design, database course design } & school \\
\hline & \multicolumn{2}{|c|}{$\begin{array}{l}\text { Enterprise C language enhancement, professional direction comprehensive training, professional practice, } \\
\text { graduation design }\end{array}$} & enterprise \\
\hline \multirow{2}{*}{$\begin{array}{l}\text { Development and innovation } \\
\text { ability }\end{array}$} & \multicolumn{2}{|c|}{$\begin{array}{l}\text { Mathematical modeling, second classroom, discipline competition and other extracurricular scientific and } \\
\text { technological activities }\end{array}$} & school \\
\hline & \multicolumn{2}{|l|}{ Actual combat of enterprise project } & enterprise \\
\hline
\end{tabular}

\section{Oriented-task Teaching Model}

In the field of professional basic courses, we encourage the teachers to adopt case teaching, and actively carry out diversified teaching methods which mobilize the enthusiasm and initiative of the students, such as problem oriented, task driven, flipping class, group discussion and so on ${ }^{[7]}$. In the field of professional courses, we encourage the teachers to teach with example guidance, project driving and engineering case with real projects and real cases to improve the students' ability to analyze and solve problems.

We took the course of principle and application of sensor network as an example, to explain the application of task driven teaching mode. According to the requirements of the task driven teaching model, the teaching content is divided into 7 practical projects. The project description is illustrated in Fig. 1, and several teaching tasks are decomposed according to the project. According to the students' situation, the students are divided into several project groups, and the 4-6 members are good. They choose the team leader. The members of the project group work out the corresponding implementation plan according to the target task so as to facilitate the better implementation of the project. The project group is based on several processes, accepting projects $\rightarrow$ independent thinking $\rightarrow$ decomposing tasks $\rightarrow$ analyzing tasks $\rightarrow$ completing tasks $\rightarrow$ evaluating tasks $\rightarrow$ completing projects, so as to realize the 
close combination of theory and practice, and improve the students' ability to solve practical problems.

In the process of project implementation, the teachers should play the role of supervision and guidance. Through the arrangement of problem homework, the teachers should guide the students to consult the data themselves, carry out the discussion before the class, realize the inquiry teaching, and the teachers can also give the attention and effect in the demonstration project operation in the classroom. Under the help of the task and the guidance of the teacher, the students achieve the expected learning effect according to the implementation plan and promote the effective implementation of the project.

After the completion of the task, the teachers need to summarize all the projects, and the team leader of each project group expounds design ideas, implementation plans, progress process and completion of the project. The teachers summarize the situation which completed the task, as well as the learning, practice, communication and team cooperation ability of the members of the project group. The overall evaluation of the project and suggestions for improvement are given.

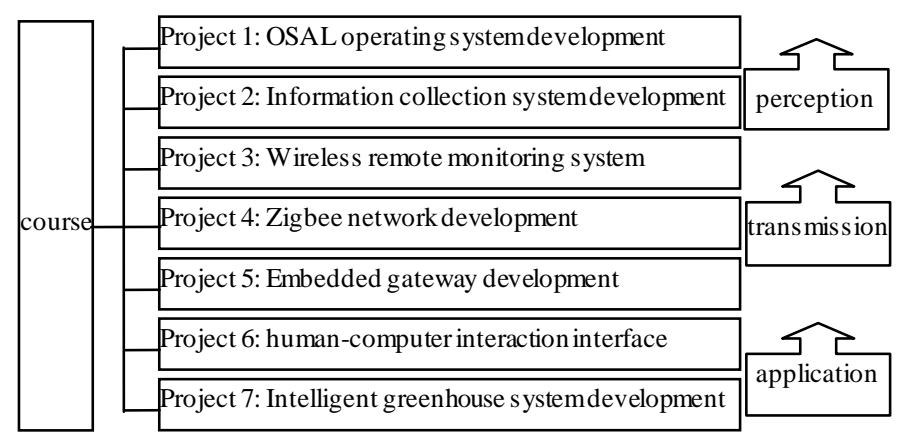

Fig. 1. The description of project

\section{Oriented-cooperation Curriculum}

We should make full use of cooperative education with Chinasoft international, and make clear that schools and enterprises undertake the hours, credits and the proportion of the curriculum modules in the talent training program. According to 2.5 years of public foundation and professional basic courses, 0.5 years of professional direction and professional practice courses (the student carry out practice training in enterprises), 1 years of the middle soft international cooperation enterprise practice, that is, "2.5+0.5+1" training mode to organize education and teaching. Among them, the enterprise takes 17.5 credits, accounting for $9.6 \%$ of the total credits, 30.5 credits and $16.8 \%$ of the total credit. The school assumes 102.5 credits, $56.5 \%$ of the total credits, 31 credits and $17.1 \%$ of the total credit. We implement the training program jointly, implement the training process jointly, build the practice base jointly, and test the quality of training jointly with enterprise. Through real enterprise environment, we carry out professional practice activities such as cognitive practice, curriculum design, professional practice and graduation practice, and improve the professional practice ability of students. We pay attention to engineering and social practice, provide students with real engineering and social situation and real practice environment, and achieve seamless docking with the post.

TABLE III. THE HOURS AND CREDITS ALLOCATION

\begin{tabular}{|c|c|c|c|c|c|c|}
\hline \multirow{2}{*}{ Bear party } & \multirow{2}{*}{\multicolumn{2}{|c|}{ link }} & \multicolumn{2}{|c|}{ School hours } & \multicolumn{2}{|c|}{ credit } \\
\hline & & & Number & $\begin{array}{c}\text { Percentage } \\
(\%)\end{array}$ & Number & $\begin{array}{c}\text { Percentage } \\
(\%)\end{array}$ \\
\hline \multirow{4}{*}{ School } & \multicolumn{2}{|c|}{ theory } & 1836 & 77.2 & 102.5 & 56.5 \\
\hline & \multirow{2}{*}{ practice } & In class & 152 & 6.4 & 8 & 4.4 \\
\hline & & focus & & & 23 & 12.7 \\
\hline & \multicolumn{2}{|c|}{ total } & 1988 & 83.6 & 133.5 & 73.6 \\
\hline \multirow{4}{*}{ enterprise } & \multicolumn{2}{|c|}{ theory } & 312 & 14.3 & 17.5 & 9.6 \\
\hline & \multirow{2}{*}{ practice } & In class & 30 & 2.1 & 2.5 & 1.4 \\
\hline & & focus & & & 28 & 15.4 \\
\hline & \multicolumn{2}{|c|}{ total } & 342 & 16.4 & 48 & 26.4 \\
\hline \multicolumn{3}{|c|}{ total } & 2330 & 100 & 181.5 & 100 \\
\hline
\end{tabular}

\section{E. Oriented-integration Practice}

According to the principle of cultivating the ability training as the core of the training of applied talents, according to the professional characteristics and post demand, we formulate the practical teaching system of basic ability, comprehensive ability, professional ability, and the continuous line of practice for the whole four years ${ }^{[8]}$. At the same time, the proportion of practical teaching links is increased. The practical teaching credits are not less than $30 \%$ of the total credits. The increase of this proportion is not only reflected in the credit score, but also more important in the teaching of experiment and practice. In professional courses, we can reduce the fragmented and confirmatory course experiments, increase the design, comprehensive and innovative experimental training, and strengthen the students' practical and innovative ability.

We develop the laboratory development management system with enterprises, and take more students use their spare time to independently enter the laboratory for professional practice. Students can carry out the two class activities and practice links in the open laboratory, such as discipline competition, scientific and technological innovation, and graduation design and so on. The experiment box of the Internet of things developed by professional teachers has been used in the course of theoretical courses and practical links in this major. The intelligent home model and intelligent transportation system develop jointly with enterprises have exercised the teachers' business ability and students' participation consciousness, and also provided the practice field for students to participate in various disciplines competition at all levels.

\section{F. Oriented-innovation Practice of Second Class}

In order to improve the students' professional quality and practical ability, we will draw up a detailed breakdown of the second class credits in the talent development plan. And the professional community of IOT has been established and equipped with professional tutors. The main activities of the 
professional associations are mainly to participate in the competition of various disciplines, participate in the research projects of teachers and the research and development of experimental equipment and instruments. We design the second class practice teaching content and program based on the professional ability training "project + class tutor + student team". By setting up a platform for professional societies, and under the guidance of professional mentors and class mentors, students will actively participate in various subject competitions and other scientific, technological and cultural activities, the annual college student science and technology event month, the Internet of Things Innovation Competition, the Electronic Design Contest, and the Embedded Design Contest and so on. With all kinds of disciplines competition as a carrier, we should cultivate students' ability to develop and innovate, develop their personality and develop their strengths. The design of the second classroom session is shown in Table 4.

TABLE IV. THE CREDIT S OF THE SECOND CLASSROOM

\begin{tabular}{|c|c|c|c|}
\hline type & Activity name & Semester & credit \\
\hline \multirow{3}{*}{$\begin{array}{l}\text { Academic } \\
\text { lecture }\end{array}$} & Professional introduction & 1 & 0.5 \\
\hline & Lecture on career planning & 2 & 0.5 \\
\hline & $\begin{array}{l}\text { A series of lectures on professional } \\
\text { knowledge of IOT research team }\end{array}$ & $2-5$ & 0.5 \\
\hline \multirow{5}{*}{$\begin{array}{c}\text { Professional } \\
\text { skills }\end{array}$} & Computer grade test - two level certificate & $2-8$ & 2 \\
\hline & $\begin{array}{l}\text { Design and development training of } \\
\text { computer network }\end{array}$ & 5 & 2 \\
\hline & $\begin{array}{c}\text { Design and development training of single } \\
\text { chip microcomputer }\end{array}$ & 5 & 0.5 \\
\hline & $\begin{array}{c}\text { Design and development training of } \\
\text { embedded system }\end{array}$ & 5 & 0.5 \\
\hline & $\begin{array}{l}\text { Design and development training of the } \\
\text { Internet of things system }\end{array}$ & 5 & 0.5 \\
\hline \multirow{3}{*}{$\begin{array}{l}\text { Nurturance } \\
\text { education }\end{array}$} & Class tutor activities - habit formation & $1-4$ & 0.5 \\
\hline & $4+X$ reading notes & $1-8$ & 0.5 \\
\hline & Volunteer activities & 1 & 0.5 \\
\hline \multirow{4}{*}{$\begin{array}{c}\text { Discipline } \\
\text { competition }\end{array}$} & $\begin{array}{l}\text { College Students' Scientific and } \\
\text { Technological Activities Month }\end{array}$ & $1-7$ & $0.5-6$ \\
\hline & $\begin{array}{c}\begin{array}{c}\text { National College Students' Embedded } \\
\text { Innovation Design Competition }\end{array} \\
\end{array}$ & $5-6$ month & \\
\hline & \begin{tabular}{|c|} 
National University of Biology Innovation \\
Design Competition \\
\end{tabular} & $5-6$ month & \\
\hline & $\begin{array}{c}\text { National College Students' Electronic } \\
\text { Design Contest }\end{array}$ & $5-6$ month & \\
\hline \multirow{3}{*}{$\begin{array}{c}\text { Professional } \\
\text { quality }\end{array}$} & Industry introduction & 2 & 0.5 \\
\hline & Lecture on employment guidance & 7 & 0.5 \\
\hline & Interview technique lecture & 7 & 0.5 \\
\hline
\end{tabular}

\section{TALENT TRAINING FEATURES}

After four years of reform and practice of talent training mode, the training model of " $2.5+0.5+1.0$ " is the first practice in the same colleges and universities in our province, which has accumulated the experience for reference and promotion, which greatly enhanced the social adaptability of the training of Applied Talents in private colleges and Universities. Ability. The innovation of personnel training under the cooperation of schools and enterprises is mainly manifested as:

- Education concept innovation. A collaborative education system of applied talents training is constructed based on the general thought of talent training in cooperation of school and enterprise.

- Develop model innovation. In the same province of our province, we have pioneered the training mode of "2.5+0.5+1.0" and "3+1" for deep cooperation between schools and enterprises.

- Cultivation means innovation. The 5R of enterprise is introduced the training process of talent, that is, the real enterprise environment, the real project manager, the real development project, the real work pressure, the real job opportunities.

\section{CONCLUSION}

In a word, the talent training model is related to the real realization of the transformation and development. In the background of the transformation and development of Changchun Guanghua University, some key problems in the university enterprise depth cooperative education system suitable for the transformation of the Internet of things to the application type are explored, and the talents training mode is improved and perfected to form a relatively perfect teaching concept and practice system of school enterprise synergy education. The disconnection between the theoretical knowledge of students' study in school and the actual work in this industry can be effectively solved. The talent training model is conducive to the improvement of students' professional core competence and employment competitiveness.

\section{ACKNOWLEDGMENT}

This work was financially supported by the Jilin new engineering research and practice project 'Reform and practice of school enterprise cooperative education mode for engineering majors in private colleges and universities".

\section{REFERENCES}

[1] Gu Yongan. On the transformation and development of newly established universities [M]. Beijing: China Social Sciences Press, 2012:5-30. In Chinese

[2] Zhao Ruiyu. Reflections on the personnel training mode of Applied Technology University [J]. School Park, 2014 (1): 18-19. In Chinese

[3] Zhang Dejiang. Orientation and mode of application oriented talents training [J]. higher education in China, 2011 (18) 24-26. In Chinese

[4] Li Xiaoguang, Zhang Dejiang, Li Wenguo, Zhang Yong. Deep cooperation between school and enterprise, training applied talents [J]. teaching research, 2017 (40) 96-101. In Chinese

[5] Guo Fuchun. Building platform for school enterprise cooperation and strengthening personnel training mechanism [J]. Teaching in Chinese universities, 2011 (5): 72-74. In Chinese

[6] Ma Jun, Ceng Xiangjun, He Chunfang et al. Exploration on teaching reform of school enterprise cooperation in running schools [J]. Journal of electrical and electronic education, 2009, (31) 2: 17-18. In Chinese

[7] Shen Jiajun, Ling Dai Jian, Deng Shejun. Exploration of school enterprise cooperation oriented to the training of outstanding engineers [J]. Education and teaching forum, 2013 (2): 200-202. In Chinese

[8] Sun Bai Ming, Cui Shuxin, Tian Rui. Research on the construction of school enterprise cooperation platform for high end skilled personnel training [J]. Chinese university teaching, 2011 (9): 84-86.In Chinese 